\title{
JUSTIFIKASI KEPERLUAN PENAHANAN REMAN MENURUT PERUNDANGAN ISLAM DAN SIVIL
}

\section{Justification of Necessity of Remand According to the Islamic and Civil Law}

\author{
Fathin Shahirah Abd Rahim * \\ Wafaa' Yusof (Dr.) ** \\ Nurbazla Ismail $* * *$
}

\begin{abstract}
Remand detention is an additional detention required to complete the investigation of criminal cases that cannot be resolved within twenty-four hours. Enforcement of remand detention under criminal law in Malaysia is enacted under section 117 of the Criminal Procedure Code (CPC). However, this provision is not provided under shariah criminal procedure in Malaysia which results in presumption arises that this procedure is not important. Ironically, the importance of remand detention as one of the investigation procedure of suspect in criminal cases has been discussed among Islamic jurists.
\end{abstract}

* Centre for Contemporary Fiqh and Shariah Compliance, Faculty of Islamic Studies, National University of Malaysia, fathinrahim94@, gmail.com

** Centre for Contemporary Fiqh and Shariah Compliance, Faculty of Islamic Studies, National University of Malaysia,wafaa@ukm. edu.my

*** Centre for Contemporary Fiqh and Shariah Compliance, Faculty of Islamic Studies, National University of Malaysia, missza@ukm. edu.my 
Therefore, this paper aims to justify the importance of remand detention according to the Islamic and civil perspectives. This is a qualitative study, which applies the content analysis framework of a few Islamic books, academic materials and others. This paper discovers that temporary detention has been practiced since the time of the Messenger of Allah (PBUH) and it is permissible by majority of Islamic scholars, because such remand detention is not intended to punish, but rather to investigate and prevent the suspect from running away. In addition, it is also intended to prevent the suspect from manipulating evidences and disturbing other witnesses who can assist the investigation process.

Keywords: Remand Detention, Suspect, Jurisdiction of Shariah Crimes, Interrogation, Pre-trial

\section{PENGENALAN}

Enakmen-enakmen Tatacara Jenayah Syariah adalah berada di bawah bidang kuasa negeri manakala Kanun Prosedur Jenayah adalah berada di bawah bidang kuasa Persekutuan. Walau bagaimanapun, penulis mendapati terdapat beberapa lacuna undang-undang dalam Enakmen Tatacara Jenayah Syariah (ETJS) yang dilihat bertentangan dan berbeza dengan Kanun Prosedur Jenayah sendiri (KPJ).

Antara lacuna undang-undang yang jelas dan ketara berlaku adalah ketiadaan peruntukan mengenai penahanan reman dan tahanan melebihi 24 jam dalam ETJS. Perkara ini didapati bertentangan dengan apa yang terkandung dalam KPJ sebagai akta ibu bagi undang-undang tatacara jenayah di Malaysia. Akta ini jelas memperuntukkan undang-undang mengenai kedua-dua tatacara di bawah seksyen 117 KPJ. Begitu juga dengan kebolehterimaan pernyataan suspek sebagai satu keterangan dalam mahkamah semasa proses soal siasat. Hal ini kerana ETJS tidak menerima pernyataan yang diberikan oleh suspek semasa soal siasat (pra perbicaraan) manakala seksyen 113 dan 112 KPJ Pindaan (Akta A1274) menerima pernyataan berkenaan bagi tujuan pembelaan 
suspek atau tertuduh dalam perbicaraan di mahkamah. Justeru itu, penulisan ini menjustifikasikan keperluan penahanan reman itu sendiri dari sudut hukum syarak.

\section{KEPERLUAN PENAHANAN REMAN MENURUT HUKUM SYARAK}

Penahanan reman dalam Islam bukanlah merupakan suatu isu yang baru. Ianya telah lama diperdebatkan oleh para ulama dan fuqaha yang mahir dalam perundangan Islam sejak zaman dahulu lagi. Bahkan Baginda Rasulullah SAW turut menahan reman seseorang yang disyaki bersalah bagi tujuan penyiasatan. Penahanan melebihi 24 jam adalah sangat penting bukan sahaja bagi mengelakkan kerencatan proses menegakkan keadilan berlaku bahkan ianya bagi mengelakkan perspektif negatif masyarakat tentang kelemahan pihak penguatkuasa agama (PPA). ${ }^{1}$ Ianya juga bagi tujuan proses penyiasatan diadakan. ${ }^{2}$

\section{Konsep Penahanan Reman Menurut Hukum Syarak}

Ashraf Md. Hashim dalam bukunya yang berjudul "Rights of Suspect and Accused Under Islamic and Malaysia Law" yang merujuk kitab al-Muhadhab daripada al-Shirazi penahanan adalah sinonim dengan perkataan al-habs yang membawa maksud mengelak atau menghalang (al-man ), memegang dan menyimpan (al-imsak) serta merupakan kata lawan kepada melepaskan dan membebaskan (al-takhaliyah). Perkataan ini turut digunakan dalam konsep al-waqf dan penjara (al-sijn, al-mahbas). Keduaduanya mempunyai makna yang berkait rapat dengan istilah alhabs. Sebenarnya, al-waqf adalah tindakan menghalang seseorang mengambil atau merampas harta daripada pemiliknya dan penjara adalah tempat untuk menempatkan pesalah atau tertuduh daripada melarikan diri. Kebanyakan para fuqaha menggunapakai

Amin al-Jarumi. Perspektif Umum Prosiding Mahkamah dalam Syariat Islam: Prinsip-prinsip Prosiding Mahkamah dalam Syariat Islam ( Shah Alam: UPENA, 2006), 98.

2 Siti Zalikhah Md. Nor, "Kanun Jenayah Syariah Suatu Penilaian”, dalam Abdul Basir Mohammad et. al. (pnyt), Isu Syariah dan Undang-undang Siri 4. (Bangi: Jabatan Syariah UKM, 2012), 45. 
perkataan al-habs bagi menahan seseorang dalam sesebuah tempat dan istilah lain yang digunakan adalah al-sijn. Namun, terdapat juga segelintir fuqaha dalam kitab Majmū ' Fatāwa yang memilih untuk menggunakan istilah lain iaitu al-ta'awiq (menghalang) iaitu menghalang seseorang daripada ia bergerak bebas dengan cara menahannya di dalam rumah mahupun di masjid atau dirinya diiringi seseorang (al-mulāzamah). ${ }^{3}$ Definisi daripada golongan ini bukan hanya menekankan penahanan seseorang di sesuatu tempat, malah yang paling penting adalah tindakan menghalang seseorang itu daripada bebas. Pendapat kedua ini tidak dibantah oleh para fuqaha yang lain walaupun mereka mendefinisikan alhabs sebagai menahan seseorang dalam penjara, namun mereka turut mengiktiraf kaedah lain seperti al-mulāzamah ataupun altaghrīb. ${ }^{4}$

Selain itu juga, Ahmad Fathi Surur turut berpandangan bahawa penahanan sementara adalah meletakkan suspek ke dalam penjara semasa dalam tempoh penyiasatan sehingga selesainya proses perbicaraan di mahkamah. ${ }^{5}$ Kenyataan beliau disokong oleh Siti Zubaidah Ismail yang menjelaskan dalam bukunya: "Undangundang Tatacara Jenayah Syariah" bahawa reman adalah satu konsep penahanan yang dijalankan ke atas seseorang bagi tujuan pemeriksaan lanjut dan dengan ketiadaan waran. Penahanan disebabkan tohmahan ini dan disebut dalam kalam bahasa Arab sebagai al-habs al-tuhmah bermaksud penahanan oleh kerana kewujudan tohmahan, sebenarnya diharuskan bagi mendedahkan kebenaran tentang penglibatan seseorang dalam suatu kes jenayah. Walau bagaimanapun, beliau mengkategorikan konsep penahanan reman dan penahanan sementara kepada dua konsep yang berbeza. Penahanan reman menurut Siti Zubaidah adalah bertujuan untuk melengkapkan maklumat dan siasatan supaya jenayah yang disyaki ke atas seseorang itu dapat dipastikan kebenarannya sekaligus membuktikan bahawa pihak berkuasa memerlukan sedikit masa

3 Ibn Taymiyyah, Aḥmad 'Abd al-Ḥalīm. Majmū' Fatāwā (Kuwayt: Mațba'ah al-Hukūmah, 1966), 201.

4 Ashraf Md. Hashim, Rights of Suspect Accused Under Islamic and Malaysian Law (Kuala Lumpur: International Law Book Services, 2004), 73.

5 Surūr, Aḥmad Fatḥ̄i, al-Wasìt fì Qānūn al-Ijrā'āt al-Jazā 'iyyati (alQāhirah: Dār al-Nahụah al-‘Arabiyyah, 1985), 623. 
untuk menyiapkan proses penyiasatan tersebut. Pernyataan beliau jelas menunjukkan keperluan kepada suatu peruntukan berkaitan tatacara penahanan reman dalam ETJS di Malaysia sememangnya tidak dapat disangkal lagi. Manakala, penahanan sementara pula adalah menahan seseorang dalam tempoh tertentu sebelum dibicarakan di mahkamah dalam keadaan suspek tidak dibebaskan dengan jaminan mahupun ketiadaan jaminan dan ianya bertujuan bagi mengelakkan seseorang pesalah itu melarikan diri ke luar negara. ${ }^{6}$ Demikian juga dengan Wafaa' Yusof yang menjelaskan bahawa penahanan reman merupakan salah satu mekanisme dalam pengendalian siasatan orang yang disyaki melakukan jenayah atau tertuduh setelah mereka ditangkap. ${ }^{7}$

Namun, Zainal Azam Abd Rahim dalam kajiannya yang bertajuk "Acara Jenayah dan Keperluan Pembuktian: Satu Tinjauan Ringkas Mengenai Beberapa Isu Berkaitan dari Perspektif Syariah dan Fiqh", mengatakan bahawa penahanan reman atau sementara ini melibatkan orang-orang yang disyaki melakukan sesuatu jenayah atau kemungkaran dan pihak berkuasa berkeperluan untuk meneliti terlebih dahulu bentuk kes yang terlibat. Beliau memegang takrif bahawa kemungkaran yang boleh diambil tindakan ialah kemungkaran yang dilakukan secara terang-terangan, maka sudah semestinya kes seperti itu memerlukan tertuduh itu ditahan reman. ${ }^{8}$

Oleh hal yang demikian, konsep sebenar penahanan reman adalah penahanan yang bersifat sementara, bukanlah bersifat menghukum. Tujuannya adalah untuk menjalankan penyiasatan ke atas orang yang disyaki dengan meletakkannya di bawah jagaan dan pantauan pihak berkuasa.

$6 \quad$ Siti Zubaidah Ismail, Undang-undang Tatacara Jenayah Syariah. (Kuala Lumpur: Dewan Bahasa dan Pustaka, 2016), 120.

7 Wafaa'Yusof, "Tatacara Penahanan Pra Perbicaraan Jenayah Syariah di Malaysia: Analisis Menurut Pandangan Fuqaha", Journal of Contemporary Islamic Law, Vol 1 (1) (2016): 39-54.

8 Zainal Azam Abd Rahim, “Acara Jenayah dan Keperluan Pembuktian: Satu Tinjauan Ringkas Mengenai Beberapa Isu Berkaitan dari Perspektif Syariah dan Fikah", dalam Abdul Monir Yaacob \& Siti Shamsiah Md. Supi (pnyt). Pendakwaan dan Penyiasatan: Konsep dan Amalan (Kuala Lumpur: Institut Kefahaman Islam Malaysia, 2003), 59. 


\section{Tempoh Tahanan dan Pihak yang Diberi Kuasa untuk Mengeluarkan Perintah Reman}

Para fuqaha berbeza pendapat mengenai tempoh tahanan iaitu menurut al-Mawardī dan Abū 'Abdullah Zubayr daripada golongan mazhab Syafii berpandangan bahawa tempoh maksimum penahanan mestilah tidak melebihi tempoh sebulan. Manakala menurut Imam Abū Hanīfah, penahanan itu tidak bolehlah melebihi tempoh sehari semalam. Ada juga yang berpendapat bahawa tempoh penahanan adalah terletak di atas pihak mahkamah dalam menentukannya dan ada juga yang berpandangan penahanan ini boleh melebihi tempoh sebulan. Pandangan ini telah diamalkan oleh Abū Ya'lā ketika beliau menjadi hakim. Beliau berpendapat bahawa jika tempoh penahanan kurang daripada 30 hari, maka ianya di bawah kebenaran hakim dan sekiranya lebih daripada 30 hari, maka ia adalah di bawah perintah atau kebenaran khalifah (head of state). Segelintir fuqaha dalam kitab al-Ahkām al-Sultāniyyah berpegang dengan pendapat yang mengatakan bahawa tempoh tahanan adalah merupakan suatu ijtihad Ketua Negara sendiri. ${ }^{9}$

Sebaliknya sebagaimana yang dinukilkan oleh Shamrahayu dalam penulisan beliau, Ibn Abī al-Dām tegas mengatakan bahawa setiap penahanan yang dibenarkan mestilah dilaksanakan dalam tempoh yang sesuai dan ia bergantung kepada keadaan suspek itu sendiri. Kebanyakan para fuqaha bersetuju memilih pandangan ini sebagai pegangan mereka. Mereka berpegang tempoh penahanan sementara atas tujuan siasatan ini tiada had masa yang terhad dan bergantung ke atas keadaan kes itu sendiri. ${ }^{10}$ Pandangan ini pula selari dengan kata-kata Ibn Qayyīm yang mengatakan bahawa jika seorang tertuduh itu pernah mempunyai rekod sabitan jenayah sebelumnya, maka ia boleh ditahan dalam tempoh yang panjang namun jika sebaliknya, tempoh penahanannya itu boleh dipendekkan. Ia bergantung ke atas keadaan dan latar belakang

9 'Alī bin Muḥammad al-Mawardī, al-Ahkām al-Sultāniyyah (alQāhirah: Dār al-Hadīth, 1988), 209.

10 Shamrahayu Abd Aziz, Issues on Enforcement of Islamic Criminal Law in Malaysia (Selangor: Malik Teraju Ria 2011), 112. 
diri tertuduh itu sendiri. ${ }^{11}$ Pendapat ini dipersetujui dan disokong oleh Ashraf Md Hashim yang mengatakan bahawa tempoh tahanan berbeza mengikut jenis kes dan keperluan penyiasatan kes itu sendiri. ${ }^{12}$

Walau bagaimanapun, kuasa mengeluarkan perintah penahanan reman ini adalah terhad sebagaimana menurut kajian Wafaa' Yusof yang menyebut pernyataan Wisam Mohamed Nasr pada tahun 2010 bahawa penyiasatan semasa penahanan sementara ini mestilah diperintahkan oleh pihak berkuasa dan bukanlah sewenangnya-wenangnya boleh dilakukan kerana pelaksanaannya melibatkan hak kebebasan tertuduh. ${ }^{13}$ Ulama bersepakat bahawa kuasa penahanan ini tidak hanya diberikan kepada pihak kadi semata-mata, namun diberikan kepada gabenor atau pemerintah tentera walī al-ḥarb kerana kadi diberi kuasa untuk melaksanakan hukum syarak dan dia tidak dibenarkan menahan seseorang melainkan dengan adanya hak dan terbukti sabit kesalahan. ${ }^{14}$

Begitu juga dengan pandangan al-Māwardī, Ibn Taymiyyah dan Ibn Qayyīm, dalam perundangan Islam, pihak yang boleh mengeluarkan perintah penahanan hanyalah hakim sahaja. Ia merupakan kata sepakat daripada para fuqaha ${ }^{15}$ dan pandangan ini selari dengan pendapat Shamrahayu Abdul Aziz bahawa penyiasatan menurut Islam adalah termasuk dalam konsep hisbah serta penahanan sementara ini menurut ijmak ulama mestilah mendapat kebenaran daripada pihak qadi atau pihak yang berautoriti terlebih dahulu. ${ }^{16}$

11 Ibn Qayyīm, Abū 'Abd Allāh Muhammad Ibn Ab̄̄ Bakr, al-Ṭuruq al-Hukmiyyah fi al-Siyāsah Shar iyyah (Bayrūt: Dār al-Kutub al'Ilmiyyah, 1995), 148.

12 Ashraf Md. Hashim, Rights of Suspect and Accused Under Islamic and Malaysian Law (Kuala Lumpur: International Law Book Services, 2004), 73.

13 Wafaa' Yusof, “Tatacara Penahanan Pra Perbicaraan Jenayah Syariah di Malaysia: Analisis Menurut Pandangan Fuqaha", Journal of Contemporary Islamic Law Vol 1 (1) (2016): 39-54.

14 Ibn Qayyīm, al-Turuq al-Hukmiyyah, 148.

15 Ashraf Md. Hashim. Rights of Suspect and Accused Under Islamic and Malaysian Law, 73.

16 Shamrahayu Abd Aziz, Issues on Enforcement of Islamic Criminal Law in Malaysia, 112. 
Secara ringkasnya, tempoh penahanan reman atau sementara menurut Islam yang disepakati adalah bergantung kepada suspek dan jenis atau keadaan kes itu sendiri. Sekiranya kes itu merupakan kesalahan yang berat, berkemungkinan tempoh penahanan itu akan menjadi lebih panjang. Berkenaan dengan pihak yang diberi kuasa untuk mengeluarkan perintah reman, penulis bersetuju dengan kajian dan penulisan sebelum ini bahawa hanya hakim dan pihak berautoriti sahaja yang layak untuk mengeluarkan perintah menahan reman seseorang suspek itu. Apatah lagi tatacara ini melibatkan hak asasi manusia yang sangat dititikberatkan oleh syarak.

\section{Justifikasi Keperluan Penahanan Reman Menurut Hadis dan Kaedah Fiqh}

Kajian pada tahun 2017 menampilkan beberapa perkara yang menjadi kunci perdebatan dalam menentukan aplikasi penahanan reman dalam sistem keadilan jenayah Islam. Penahanan pra perbicaraan atau penahanan reman sebagai suatu mekanisme penyiasatan merupakan antara perkara yang diperincikan dalam kajian tersebut. Hal ini kerana menurut analisis kajian terhadap beberapa penulisan ulama kontemporari menunjukkan bahawa penahanan sementara dibolehkan bagi tujuan siasatan terhadap tertuduh dan juga bagi tujuan membantu tertuduh dalam proses penyiasatan sehinggalah jelas terbukti dirinya benar-benar boleh didakwa. ${ }^{17}$

Pernyataan Wafaa' Yusof dikuatkan lagi dengan kewujudan hadis Nabi SAW bahawa Rasulullah SAW pernah melaksanakan penahanan yang bersifat sementara ke atas seorang lelaki selama sehari semalam yang dituduh melakukan jenayah pembunuhan. ${ }^{18}$ Baginda menahan lelaki terbabit atas tujuan penyiasatan (siasatan awal) serta mendapatkan kenyataan daripadanya dan sebagai salah satu langkah berhati-hati. Begitu juga dengan hadis daripada

17 Wafaa' binti Yusof, “Tatacara Pra Perbicaraan Jenayah Syariah Terhadap Suspek Kanak-Kanak: Analisis Perundangan di Malaysia”, Tesis Dr. Fal, (Fakulti Undang-undang: Universiti Kebangsaan Malaysia, 2017), 131.

18 Muhammad Fathi Yusof, Keindahan Undang-undang Islam (Selangor:

Best Brains Asia Publications, 2017), 110. 
al-Hassan bahawa terdapat sekumpulan lelaki daripada Hijaz telah bergaduh dan salah seorang daripada mereka telah menjadi korban, maka Rasulullah SAW mengutus seseorang untuk menyelesaikan masalah itu. Utusan itu telah menahan mereka yang terlibat dalam pergaduhan tersebut. Walaupun terdapat segelintir ulama tidak bersetuju dengan penahanan jenis ini kerana didakwa tidak dipraktikkan pada zaman Saidina Abū Bakar RA, namun majoriti ulama lain menerimanya dan sah dipraktikan. Ibn Qayyīm dalam kitab Tamlīh Qudhat al-Andalus dār al- 'Alaq al-Jadih menjelaskan, apabila seorang tertuduh semasa proses pendakwaan sama ada diketahui keadaannya atau sebaliknya dan sama ada keadaannya baik atau buruk, maka dia perlu ditahan sehingga ternyata keadaannya. ${ }^{19}$

Di samping itu juga, penguatkuasaan mekanisme ini memberi jaminan keselamatan bukan hanya kepada saksi dan orang awam, malahan kepada suspek sendiri. Ia juga bagi memastikan proses siasatan berjalan lancar dan hukuman dapat dilaksanakan apabila tertuduh diputuskan bersalah. Suspek kebiasaannya diletakkan di bawah jagaan pihak berkuasa dalam satu tempoh tertentu jika dia mendatangkan bahaya kepada orang awam atau pihak-pihak yang terbabit atau menjejaskan keselamatan penyiasatan yang sedang dilakukan dan jika ditakuti suspek melarikan diri. Penahanan reman ini melibatkan lokasi penahanan yang telah digazet oleh undang-undang dalam suatu tempoh tertentu yang telah ditetapkan oleh undang-undang setelah seseorang dituduh atau disyaki telah melakukan sesuatu yang bertentangan dengan undang-undang jenayah dan seumpamanya. ${ }^{20}$ Selain itu, keperluan penahanan reman yang lain adalah bagi mengelak pihak penguatkuasa bimbang dan khuatir berlakunya kehilangan bahan bukti yang

19 Abū Hassan al-Nubayhī, Tamlīh Qudhat al-Andalus (Beirut: Dār al'Alaq al-Jadīd, 1980), 154.

20 Ahmad Azam Shariff, "Prosedur Siasatan dan Pendakwaan Jenayah Syariah: Lakuna dalam Peruntukan Undang-undang Jenayah Syariah di Malaysia", Tesis Dr. Fal (Fakulti Undang-undang: Universiti Kebangsaan Malaysia, 2012), 186. 
sangat penting semasa tempoh soal siasat suspek atau tertuduh sekiranya dia itu dilepaskan. ${ }^{21}$

Seterusnya, penahanan seperti ini bertujuan melindungi masyarakat daripada dicederakan oleh suspek dan menghalangnya daripada melarikan diri. ${ }^{22}$ Wafaa' Yusof yang mempunyai pandangan yang sama dengan Sa eedy ${ }^{\mathrm{c}} \mathrm{Ali}$, menegaskan dalam penulisannya yang bertajuk "Tatacara Penahanan Pra Perbicaraan Jenayah Syariah di Malaysia: Analisis Menurut Pandangan Fuqaha" bahawa penahanan pra perbicaraan adalah penting bagi menjamin tatacara siasatan awal dengan cara membenarkan pihak penguatkuasa menempatkan tertuduh dalam jagaan untuk melancarkan proses penyiasatan ke atasnya, menghalang tertuduh daripada mengulangi jenayah yang sama atau yang baru, mengelakkan suspek daripada melarikan diri daripada jenayah yang telah dilakukannya itu seterusnya menyebabkan keberadaan suspek tidak dapat dikesan, memanipulasi dan menganggu bahanbahan bukti serta saksi (termasuk mangsa) yang berkaitan dengan jenayah dan bagi memelihara ketenteraman orang awam daripada suspek. Keempat-empat keadaan tersebut menjustifikasikan penerimaan penahanan sementara ini sebagai salah satu tatacara untuk menegakkan keadilan. Walau bagaimanapun, perlu ditekankan di sini bahawa penahanan ini hanya boleh dilaksanakan sekiranya wujud qarinah yang kuat dan penzahiran syak wasangka (ghalabah al-z̧an) terhadap suspek. Jika tidak, ianya tidak dibenarkan kerana telah menceroboh hak kebebasan tertuduh. Penahanan jenis ini bukanlah merupakan suatu bentuk hukuman selagi mana mereka tidak dibuktikan bersalah oleh pihak mahkamah. Para ulama menegaskan sekiranya pihak berkuasa ingin menahan seorang suspek, mereka mestilah mempunyai

${ }^{21}$ Salman Muhammad, "The Right to a Fair Trial under Saudi Law of Criminal Procedure", Tesis Dr. Fal (Brunel University (London), 2013), 86.

22 Sa'eedy 'Ali, "Different Cases of Imprisonment in Islam", Journal of Faculty of Law and Political Science (FALL), vol 41 (3) (2011): 185-199. 
alasan yang kukuh atau syak wasangka ke tahap ghalabah al-zann dan bukannya sekadar al-ẓan. ${ }^{23}$

Mekanisme ini menurut Wafaa' Yusof lagi yang bersetuju dengan pandangan Siti Zubaidah dan Ahmad Azam Shariff sebelum ini, bertujuan untuk mengelak berlakunya tohmahan terhadap suspek, menghalang orang yang benar-benar bersalah dari melarikan diri dan menyekat penyalahgunaan kuasa. Lazimnya penahanan reman bertindak sebagai satu mekanisme dalam membendung semua perkara sedemikian dari berlaku sehinggalah kebenaran dibuktikan dan keraguan dihapuskan. Keadaan ini jelas dibuktikan apabila usaha awal para penguat kuasa undang-undang ini berkuat kuasa sehingga satu kes prima facie berjaya dibuktikan terhadap suspek dan diteruskan prosiding pendakwaan dan perbicaraan. Sebaliknya sesuatu kes akan diketepikan dan suspek akan dilepaskan serta dibebaskan jika tiada bukti yang mencukupi untuk mewujudkan satu kes prima facie terhadap suspek atau kes prima facie gagal dibuktikan berlaku dan tiada lagi tohmahan terhadapnya apabila dia dibebaskan. ${ }^{24}$

Daud Muhammad turut menambah dalam penulisannya yang bertajuk "Konsep Penyiasatan di dalam Islam", tindakan menangkap dan menahan seseorang itu dianggap perlu dan tidak dinafikan bagi melancarkan proses penyiasatan dan mendapatkan keterangan yang lengkap. ${ }^{25}$ Keadaan ini seiring dengan hadis riwayat Muslim:

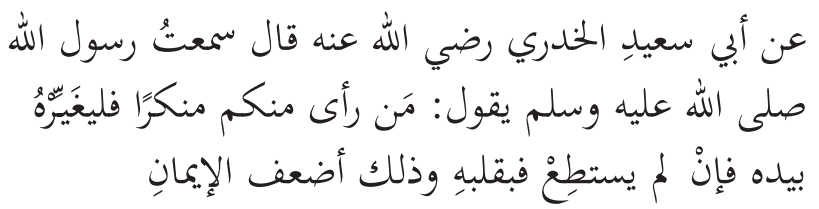

23 Wafaa'Yusof, "Tatacara Penahanan Pra Perbicaraan Jenayah Syariah di Malaysia: Analisis Menurut Pandangan Fuqaha", Journal of Contemporary Islamic Law. Vol 1 (1) (2016): 39-54.

24 Ibid.

25 Daud Muhammad, "Konsep Penyiasatan di dalam Islam", dalam Abdul Monir Yaacob \& Siti Shamsiah Md.Supi (pnyt), Pendakwaan dan Penyiasatan Konsep dan Amalan (Kuala Lumpur: IKIM, 2003), 62. 
"Sesiapa di kalangan kamu melihat sesuatu kemungkaran, hendaklah mencegahnya dengan tangan (kuasa), jika tidak mampu maka cegahlah dengan lisan (nasihat dan larangan), namun jika masih tidak mampu, maka hendaklah dia ada perasaan benci dalam hatinya akan kemungkaran itu dan ia adalah selemah-lemah iman". ${ }^{26}$

Apabila seseorang itu ditangkap dan ditahan serta gagal mendapatkan jaminan, maka dia bolehlah ditahan dalam penjara mahupun dalam jagaan pihak berkuasa dengan suatu perintah daripada hakim sebagaimana sebuah hadis daripada Abu Daud, al-Tirmīdhī dan Nasa'î iaitu:

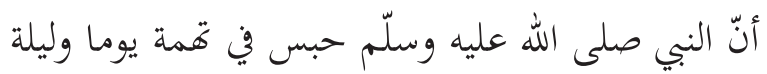

Maksudnya: "Diriwayatkan daripada Abu Hurairah $R A$ bahawasanya Rasulullah SAW telah menahan seorang lelaki oleh kerana terdapat tohmahan selama sehari semalam". ${ }^{27}$

Begitu juga dengan Zainal Azam Abd Rahim bersetuju bahawa sekiranya kesalahan atau jenayah yang dilakukan tertuduh itu adalah berat dan memerlukan masa untuk disoal siasat, maka penahanan reman bagi kesalahan seperti ini adalah dibenarkan. ${ }^{28}$ Hal ini selari dengan pendapat Ibn Qayyīm al-Jawziyyah dalam al-Ṭurūq al-Hukmiyyah iaitu sekiranya tertuduh masih tidak diketahui statusnya, maka dia boleh ditahan sehingga kedudukan sebenarnya diketahui. Akan tetapi, tuduhan yang dilakukan itu

26 Abū al-Ḥusayn 'Asākir ad-Dīn Muslim Ibn al-Ḥajjāj, Sharh alArba 'ìn al-Nawawiyyah, Kitāb Jamī' al-Sunnati wa Shurūḥaha. Bāb Bayān Kawn al-Nahī 'an al-Munkar min al-'Ima (Beirut: Mu'assasah al-Risālah, 1422H), no.hadith 34 .

27 Abū Dāwud Sulaymān Ibn al-Ash 'ath al-Azdi al-Sijistanī, Sunān Abū Dāwud, Kitāb al-Talkhis al-Habir, Bāb al-Ta'zīr (Misr: Mu'assasah Qurtubah, 1995M), no.hadith 641.

28 Zainal Azam Abd Rahim, “Acara Jenayah dan Keperluan Pembuktian: Satu Tinjauan Ringkas Mengenai Beberapa Isu Berkaitan dari Perspektif Syariah dan Fikah", dalam Abdul Monir Yaacob \& Siti Shamsiah Md. Supi (pnyt), Pendakwaan dan Penyiasatan: Konsep dan Amalan (Kuala Lumpur: Institut Kefahaman Islam Malaysia, 2003), 59. 
mestilah berasas, kemudian barulah boleh dipanggil tertuduh, bukan semata-mata tuduhan sahaja. Selain itu, begitu juga dengan tertuduh yang telah mempunyai rekod jenayah turut boleh ditahan bagi menjalankan siasatan lanjut. ${ }^{29}$

Tambahan lagi, Wafaa' Yusof ada memetik kajian perbandingan dan penulisan Mus'ab Aymān al-Ruwayshid yang menganalisis beberapa pendapat para fuqaha berkaitan maqāṣid pelaksanaan penahanan sementara. Analisis jelas membuktikan penahanan seperti ini bertujuan untuk menjaga kemaslahatan umum dan masyarakat sejagat. ${ }^{30}$ Nukilan beliau daripada hasil penulisan dan kajian Nuzar Raja Sabatai Sabra dari Jāmi'ah alNajāh al-Wațaniyyah, seterusnya mengiyakan dan membuktikan kepentingan penahanan sementara ini bagi membantu pihak berkuasa menyempurnakan perjalanan soal siasat suspek seterusnya dapat membuktikan sama ada suspek benar-benar bersalah mahupun tidak. 'Umar Said Ramadhan mengatakan bahawa antara tujuan lain penahanan pra perbicaraan ini adalah demi memelihara kemaslahatan dan ketelusan penyiasatan seperti mengelakkan tertuduh menganggu para saksi dan memanipulasi bukti-bukti yang boleh dijadikan sebagai bahan sokongan kes tersebut. ${ }^{3132}$

Kebolehterimaan penahanan seperti ini adalah berdasarkan prinsip "al-ḍrūrāt tubīh al-maḩururāt". Kepentingan penahanan ini adalah tidak lain tidak bukan bagi memberi peluang kepada pihak berkuasa untuk menjalankan proses soal siasat dan memberi tempoh masa kepada tertuduh untuk bersiap sedia bagi tujuan

29 Ibn Qayyīm, Abū 'Abd Allāh Muḥammad Ibn Abī Bakr, al-Ṭuruq al-Hukmiyyah fì al-Siyāsah Shar iyyah (Bayrūt: Dār al-Kutub al'Ilmiyyah, 1995), 148.

30 Wafaa' binti Yusof, "Tatacara Pra Perbicaraan Jenayah Syariah Terhadap Suspek Kanak-Kanak: Analisis Perundangan di Malaysia”, Tesis Dr. Fal, (Fakulti Undang-undang: Universiti Kebangsaan Malaysia, 2017), 131.

31 'Umar Sa'īd Ramaḍān, Mabād̄̄' Qānūn al-Ijrā'āt al-Janā 'iyyat (alQāhirah: Dār al-Nahḍah al-'Arabiyyah, 1993), 1: 40.

32 Wafaa' binti Yusof, "Tatacara Pra Perbicaraan Jenayah Syariah Terhadap Suspek Kanak-Kanak: Analisis Perundangan di Malaysia”, Tesis Dr. Fal, (Fakulti Undang-undang: Universiti Kebangsaan Malaysia, 2017), 131. 
pembelaan dirinya sendiri. Tertuduh akan dibawa ke mahkamah untuk membicarakan kesnya secepat mungkin setelah selesai persediaan kesnya. Hal ini bagi memastikan prinsip al-cadālah masih kekal terlaksana dan memberi peluang untuk tertuduh membela dirinya. ${ }^{33}$

Keperluan mengenai penahanan reman ini dikuatkan lagi dengan pengaplikasian pelbagai kaedah fiqh yang telah digariskan dalam Islam. Antara prinsip syariah yang terkait dalam situasi ini adalah "al-darūrāt tubih al-maḩurüât" (keperluan mengharuskan larangan) iaitu prinsip ini membenarkan sekatan kebebasan seseorang yang pada awalnya merupakan suatu perbuatan yang diharamkan. Namun atas tujuan penyiasatan, maka ianya adalah dibenarkan. ${ }^{34}$ Kedua, "al-darūrah tuqaddar bi qadarih $\bar{a}$ " (keperluan dihadkan pada kadarnya) iaitu seseorang itu boleh ditahan dalam jangka masa yang terhad sahaja. Kedua-duanya jelas menunjukkan bahawa keharusan menahan seseorang suspek dalam tempoh masa yang terhad supaya proses soal siasat dapat dijalankan ke atasnya. ${ }^{35}$ Perkara ini dimantapkan lagi dengan pandangan Imam Khațtābī, menurut tulisan Md. Akhir Yaacob, telah menjelaskan dalam sebuah hadis yang tertulis dalam Macālim al-Sunan bahawa tahanan yang dibenarkan dalam Islam hanya dua jenis penahanan sahaja iaitu tahanan atas perintah mahkamah bagi tujuan melaksanakan hukuman yang diputuskan mahkamah dan yang kedua adalah penahanan untuk tujuan proses penyiasatan. Selain daripada kedua-duanya ini, maka tiada apa-apa alasan lagi yang membolehkan seseorang itu ditahan kebebasannya untuk bergerak di atas muka bumi ini. ${ }^{36}$ Jadi, jelaslah di sini bahawa penahanan sementara sebelum perbicaraan ini diharuskan oleh

33 Ashraf Md. Hashim, Rights of Suspect and Accused Under Islamic and Malaysian Law (Kuala Lumpur: International Law Book Services, 2004), 74.

34 Muhammad Shirazi, The Rights of Prisoners According to Islamic Teachings (London: Fountain Books, 2002), 13.

35 Ahmad Azam Shariff, "Prosedur Siasatan dan Pendakwaan Jenayah Syariah: Lakuna dalam Peruntukan Undang-undang Jenayah Syariah di Malaysia", Tesis Dr. Fal, (Fakulti Undang-undang: Universiti Kebangsaan Malaysia, 2012), 186.

36 Md. Akhir Yaacob, Sistem Pemerintahan dalam Islam (Kuala Lumpur: Bahagian Hal Ehwal Islam Jabatan Perdana Menteri, 1986), 86. 
majoriti fuqaha, dengan syarat ianya bertujuan untuk melakukan penyiasatan ke atas suspek.

Penyiasatan amat penting di peringkat pra perbicaraan. Siasatan menurut Islam, merupakan suatu keperluan untuk mengelak berlakunya penganiayaan atau tohmahan ke atas seseorang yang tidak bersalah. ${ }^{37}$ Antara tujuan utama diadakan siasatan atau soal siasat adalah untuk mendapatkan keterangan daripada seseorang yang disyaki atau dituduh melakukan suatu kesalahan jenayah. Jadi, tidak hairanlah penahanan reman atau penahanan melebihi 24 jam adalah penting kerana tujuan penahanan reman adalah bagi memastikan proses soal siasat dapat dilaksanakan dengan sempurna. Seterusnya, hasil atau kenyataan daripada soal siasat itu dapat digunakan sebagai keterangan yang dapat membela nasib tertuduh dalam mahkamah. ${ }^{38}$

Tujuan penyiasatan yang lain adalah bagi mendapatkan buktibukti sama ada tertuduh itu benar-benar terlibat dengan jenayah yang disyaki ataupun tidak. Ironinya, Islam secara tidak langsung telah menggariskan tatacara sebenar proses penyiasatan yang perlu dipatuhi oleh pihak berkuasa bagi menghindari pencabulan hak kebebasan tertuduh.

Segala prosedur yang telah ditetapkan undang-undang mestilah dipatuhi oleh semua pengamal dan juga pihak penguatkuasa bagi menjamin keadilan semua pihak yang terlibat. Keadilan yang ditafsirkan oleh para ulama Islam adalah meletakkan sesuatu pada tempatnya dengan betul. Oleh itu, seseorang hakim tidak seharusnya mensabitkan seseorang dengan sabitan jenayah serta menjatuhkan hukuman tanpa bukti dan keterangan yang kukuh. Bukti dan keterangan ini antaranya diperoleh melalui soal siasat terhadap suspek dan secara tidak langsung melibatkan penahanan suspek. Malahan penahanan dilanjutkan apabila soal siasat tidak dapat diselesaikan dalam tempoh 24 jam jika semua maklumat belum sempurna dan tidak lengkap sepenuhnya. Jadi, penahanan reman ini merupakan satu keperluan yang tidak dapat dinafikan lagi dan ianya adalah selari dengan prinsip syariah. Konsep al-habs

37 Muhammad Tahmid, Menggapai Hukum Pidana Ideal Kemaslahatan Pidana Islam dan Pembaruan Hukum Pidana Nasional (Jogjakarta: Deepublish, 2016), 286.

38 Iran's Human Rights Watch, 2003. 
al-ihtiyāțì telah jelas menerangkan bahawa penahanan sementara ini adalah dibenarkan walaupun ianya bukan merupakan suatu prinsip yang muktamad dan kukuh. ${ }^{39}$

Pada hakikatnya, penahanan jenis ini diharuskan kerana bertujuan untuk menjamin kualiti dan integriti penyiasatan. Oleh itu, apabila terbukti suspek tidak bersalah, maka hendaklah dia dibebaskan dan tidak boleh terus menahannya. ${ }^{40}$ Ini bertepatan dengan prinsip perundangan "tiada jenayah dan tiada hukuman melainkan dengan nas" (لا جريمة ولا عقوبة إلا بنص). yang sama, penahanan sementara dalam Islam bukanlah bertujuan untuk menakut-nakutkan sesiapa. Namun, antara tujuannya adalah untuk mengelak tertuduh mencari helah untuk melarikan diri di samping untuk menyoal siasat tertuduh.

Tidak dapat dinafikan masih terdapat segelintir ulama tidak bersetuju dengan penahanan seperti ini kerana mereka menganggap penahanan ini merupakan satu hukuman, sedangkan ia hanyalah penahanan sementara (al-habs al-ihtiyațī) bagi tujuan penyiasatan. Bahkan bukan bagi tujuan penyiasatan sematamata, namun ia juga adalah bagi tujuan memastikan tertuduh menghadirkan diri semasa perbicaraan dalam mahkamah. Justeru, penahanan golongan kedua ini dibenarkan dengan syarat mestilah mempunyai alasan yang kukuh untuk berbuat sedemikian. ${ }^{42}$

Al-Qurțubī ada membicarakan tentang larangan menyekat kebebasan seseorang berlandaskan syak wasangka semata-mata dalam suatu kes jenayah.. Walau bagaimanapun, pandangan ini boleh dipertimbangkan semula kerana syak wasangka sering

39 Ahmad Azam Shariff, "Prosedur Siasatan dan Pendakwaan Jenayah Syariah: Lakuna dalam Peruntukan Undang-Undang Jenayah Syariah di Malaysia", Tesis Dr. Fal, (Fakulti Undang-undang: Universiti Kebangsaan Malaysia, 2012), 186.

40 Wafaa' binti Yusof, "Tatacara Pra Perbicaraan Jenayah Syariah Terhadap Suspek Kanak-Kanak: Analisis Perundangan di Malaysia", Tesis Dr. Fal, (Fakulti Undang-undang: Universiti Kebangsaan Malaysia, 2017), 131.

41 'Abd al- Qādir 'Awdah, al-Tashrī' al-Janā 'ī al-Islām Muqāranan bi al-Qānūn al-Wạ̣i '`̄ (Bayrūt: Dār al-Kitāb al-'Arabī, 2003), 241.

42 Ashraf Md. Hashim, Rights of Suspect and Accused Under Islamic and Malaysian Law (Kuala Lumpur: International Law Book Services, 2004), 73. 
kali terhasil daripada suatu aduan yang boleh dipercayai dan munasabah terhadap suatu perlakuan jenayah. Berdasarkan aduan ini kebiasaannya pihak penguatkuasa undang-undang bertindak untuk menangkap, menahan dan menyoal siasat suspek. Penyiasatan semasa dalam tempoh tahanan ini bertujuan untuk menjelaskan apa-apa perkara yang masih kurang jelas, merungkaikan persoalan fakta serta bukti dan mencari kebenaran serta keadilan. ${ }^{43}$

Misalnya di Malaysia, Ketua pegawai penguatkuasa agama negeri-negeri telah diberikan kuasa untuk melakukan penangkapan jika perlu dan setelah ditangkap, suspek atau tertuduh boleh ditahan bagi tujuan soal siasat. Walaupun begitu, dalam ETJS contohnya, tiada peruntukan mengenai penahanan sementara dan tempoh tahanan yang dibenarkan. Perkara seperti ini seharusnya diberi perhatian kerana penahanan tanpa tempoh masa yang ditetapkan bakal menggugat hak kebebasan seseorang tertuduh. Permasalahan seperti ini tidak akan selesai selagi mana tiada undang-undang memberikan had atau batasan tempoh tahanan seseorang tertuduh itu. ${ }^{44}$

Pada pendapat penulis, hadis-hadis di atas membuktikan bahawa penahanan sementara pernah dilakukan oleh Baginda Rasulullah SAW sendiri. Hal ini bagi tujuan menyoal siasat tertuduh atas sesuatu kesalahan yang dipertuduhkan ke atasnya. Sekiranya tertuduh itu didapati bersalah, maka tindakan seterusnya akan dikenakan ke atasnya. Sekiranya berlaku sebaliknya, maka tertuduh akan dilepaskan tanpa sebarang hukuman ataupun ancaman daripada Baginda. Oleh itu, penulis berpendapat bahawa penahanan lanjutan bagi tujuan penyiasatan ini jelasnya tidak bertentangan atau bersalahan dengan prinsip siyasah syariyyah. Tidak dinafikan bahawa Islam menghalang sekeras-kerasnya penahanan secara salah kerana perbuatan tersebut dianggap melanggar hak asasi individu. Akan tetapi, penahanan sementara

43 Muḥammad bin Aḥmad bin Abī Bakr bin Farạ̣ Abū Abdullah alQurțubī, al-Jāmi' li Ahkeām al-Qur'an al-Mubìn Lammā Tadmanahu min al-Sanah wa'ayyu al-Furqān, jil 6 (al-Qaherah: Dar al-Sha' bi, 1372).

44 Shamrahayu Abd Aziz, Isu Penguatkuasaan Undang-undang Jenayah Syariah di Malaysia (Kuala Lumpur: Dewan Bahasa dan Pustaka, 2016), 96. 
ini dibenarkan atas tujuan menyempurnakan proses soal siasat, menghalang suspek melarikan diri, mengelakkan suspek daripada menganggu para saksi dan bahan bukti yang dapat membantu proses penyiasatan serta bagi tujuan melindungi masyarakat daripada diusik diancam oleh tertuduh sendiri.

\section{KEDUDUKAN PENAHANAN REMAN MENURUT KANUN PROSEDUR JENAYAH}

Penahanan tertuduh bagi tujuan siasatan di bawah seksyen 117 KPJ dianggap sebagai penahanan reman. Seksyen 117 turut jelas menunjukkan bahawa sekiranya sesuatu penyiasatan itu tidak dapat disempurnakan dalam tempoh 24 jam, maka penahanan lanjutan (penahanan reman) akan dilaksanakan ke atas suspek dengan kebenaran hakim. ${ }^{45}$ Majistret adalah pihak yang berhak untuk mengeluarkan perintah reman ke atas tertuduh. Majistret yang dimaksudkan di sini ialah Majistret Kelas Pertama, Majistret Kelas Kedua dan Majistret ex-officio. ${ }^{46}$

\section{Konsep Penahanan Reman Menurut KPJ}

Maksud penahanan reman tidak dijelaskan secara terperinci dalam seksyen $117 \mathrm{KPJ}$ sendiri, namun ia dijelaskan dalam seksyen 259 KPJ yang membawa maksud "re-committal" iaitu meletakkan seseorang itu dalam jagaan pihak berkuasa seperti dalam kes Deepak Mahajan v Director of Enforcement (1991) Cr LJ 1124 (Del). Dalam State of Maharashtra v Ramesh Taurani (1997) Supp 5 SCR 463, mahkamah berpendapat bahawa permohonan untuk menjalankan penahanan reman mestilah dipersetujui oleh pihak Mahkamah sebelum mereman seseorang tertuduh itu sekaligus menyerahkan suatu notis kepada Mahkamah yang mengandungi bukti-bukti yang didapati semasa proses penyiasatan ke atas tertuduh. Seksyen 117 ini membenarkan penahanan melebihi 24 jam jika penyiasatan yang dilakukan belum sempurna. ${ }^{47}$

\footnotetext{
45 Mimi Kamariah, Pentadbiran Keadilan Jenayah di Malaysia (Kuala Lumpur: Universiti Malaya, 1991), 101.

46 Mimi Kamariah. Pentadbiran Keadilan Jenayah di Malaysia,102.

47 Srimurugan Alagan, The Criminal Procedure Code: A Commentary (Selangor: Sweet \& Maxwell, 2015), 97.
} 
Perkara ini turut dipersetujui oleh Ahmad Azam Shariff iaitu seksyen 117(1) telah mengatakan bahawa apabila seseorang itu ditangkap dan ditahan serta penyiasatan tidak dapat dihabiskan dalam tempoh 24 jam, maka pegawai polis itu mestilah dengan seberapa segera menghantar satu salinan catatan harian kepada pihak Majistret untuk memohon penahanan lanjutan dan Majistret mestilah menilai sama ada penahanan lanjutan itu perlu atau tidak. ${ }^{48}$

Sebenarnya, seksyen 117 KPJ ini telah mengalami pindaan pada tahun 2006 kerana ianya dilihat bersifat sedikit keterbukaan ke arah penderaan tertuduh. Ulasan para pengamal undangundang setelah seksyen itu dipinda adalah frasa "tangkap dahulu, siasat kemudian" itu dapat dihapuskan. Mereka juga berpendapat bahawa tempoh tahanan lanjutan selepas berlakunya pindaan lebih bersifat realistik dan mudah dikawal iaitu tempoh tahanan bagi kesalahan yang hukumannya adalah mati atau penjara melebihi 14 tahun adalah berbeza dengan tempoh tahanan bagi kesalahan yang hukumannya penjara tidak melebihi 14 tahun serta sudah semestinya ianya bertujuan bagi mendapatkan keterangan daripada pihak yang ditahan. Faktor utama pindaan dilakukan adalah bagi mengelakkan tahanan ditahan lanjut tanpa sebab yang munasabah. ${ }^{49}$

Perlu ditegaskan di sini bahawa penahanan reman dengan penahanan selepas dibicarakan adalah merupakan dua perkara yang sangat berbeza. Hal ini kerana penahanan reman adalah bagi tujuan siasatan atau "investigative detention" manakala penahanan selepas perbicaraan adalah merupakan suatu bentuk hukuman setelah disabitkan bersalah oleh pihak mahkamah. ${ }^{50}$

Secara ringkasnya, seksyen 117 KPJ telah jelas memperuntukkan mengenai penahanan reman iaitu sekiranya proses soal siasat tidak dapat disempurnakan dalam tempoh 24 jam, maka pihak penyiasat boleh memohon perintah reman daripada Majistret disertai dengan penyerahan diari catatan harian

48 Ahmad Azam Shariff, Prosedur Siasatan dan Pendakwaan Jenayah Syariah: Lakuna dalam Peruntukan Undang-undang Jenayah Syariah di Malaysia (Bangi: Universiti Kebangsaan Malaysia, 2012), 282.

49 The Malaysia Bar. 2013.

50 Sinar Harian, 2015. 
bagi membuktikan kepada Majistret suspek benar-benar perlu ditahan lanjut bagi tujuan siasatan.

\section{Tempoh Penahanan Reman dan Pihak yang Diberi Kuasa Mengeluarkan Perintah Reman}

Dalam Kanun Prosedur Jenayah di Malaysia, perintah reman atau penahanan lanjutan itu mestilah tidak melebihi tujuh hari bagi kesalahan yang hukumannya tidak melebihi 14 tahun penjara dan tidak melebihi 14 hari tempoh reman bagi kesalahan yang hukumannya penjara lebih daripada 14 tahun atau hukuman mati. ${ }^{51}$

Setelah tamat tempoh penahanan 24 jam namun sesi soal siasat belum selesai serta ada sebab-sebab untuk mempercayai bahawa kenyataan tuduhan itu berasas, maka pihak berkuasa mestilah membawanya ke Majistret untuk permohonan perintah tahanan lanjutan yang tidak melebihi 14 hari keseluruhannya dengan syarat pihak polis itu mestilah menyatakan sebab dan alasan mengapa penyiasatan itu tidak dapat diselesaikan dalam tempoh yang ditetapkan. ${ }^{52}$

Berkenaan dengan pihak yang mempunyai kuasa untuk mengeluarkan perintah reman, hanya Majistret yang berhak untuk melakukan sedemikian. Majistret berkuasa dalam mengeluarkan perintah untuk menahan seseorang melebihi tempoh 24 jam menurut seksyen 9 KPJ. Namun, perintah reman mestilah diadakan di mahkamah terbuka. Menurut seksyen 7 KPJ, apaapa persidangan bagi tujuan penyiasatan atau perbicaraan yang berkaitan dengan jenayah mestilah diadakan di mahkamah yang terbuka dan orang ramai boleh memasukinya. Apabila permohonan reman dibuat, maka pegawai penyiasat dikehendaki memberi butir-butir siasatan yang telah diperolehi semasa siasatan dalam tempoh 24 jam itu serta menyerahkan diari siasatan kepada pihak Majistret (seksyen 119). Walau bagaimanapun, pihak Majistret berhak untuk menolak permohonan penahanan reman daripada pegawai penyiasat jika ia mendapati bahawa penahanan lanjutan tidak perlu. ${ }^{53}$

51 The Malaysian Bar. 2013.

52 Human Rights Watch. 2006.

53 Lee Chong Fook et. al, The Process of Criminal Justice: Investigation and Pre-Trial Proceedings (Singapura: LexidNexis, 2010), 121. 
Kenyataan di atas dikuatkan lagi dengan akhbar Sinar Harian pada tahun 2005 iaitu menurut Seksyen 117 KPJ lagi, majistret hanya wajar membuat perintah reman sekiranya didapati bahawa penyiasatan tidak boleh diselesaikan dalam masa 24 jam dan terdapat alasan-alasan untuk menahan orang tersebut dalam lokap sementara siasatan dijalankan oleh polis. Majistret tidak boleh menerima sahaja permohonan polis untuk penahanan reman. Majistret harus berpuas hati bahawa terdapatnya alasan-alasan untuk memberikan perintah reman tersebut, dan alasan-alasan ini wajar dikemukakan oleh polis. Di samping itu, alasan-alasan yang dikemukakan juga mesti berkaitan dengan keperluan polis untuk melanjutkan tahanan orang tersebut. ${ }^{54}$

Penulis dapat menyimpulkan bahawa tempoh penahanan bergantung kepada jenis kesalahan dan hukuman yang akan dikenakan ke atas tertuduh. Di samping itu, hanya Majistret yang layak mengeluarkan perintah menahan reman seseorang, bukanlah pihak polis sendiri. Hal ini bagi mengelakkan berlakunya penindasan atau penyalahgunaan kuasa dalam kalangan pihak berkuasa. Majistret sendiri yang akan menilai sama ada penahanan reman ke atas orang yang disyaki perlu atau tidak berdasarkan buku catatan harian tersebut.

\section{Kedudukan Penahanan Reman Menurut Kanun Prosedur Jenayah}

Objektif paling utama penahanan lanjutan atau penahanan reman adalah untuk memberi masa kepada pegawai polis bagi menjalankan siasatan yang boleh membawa kepada pendakwaan ke atas sesuatu kesalahan. ${ }^{55}$ Walau bagaimanapun, pihak Majistret berhak untuk menolak permohonan penahanan reman daripada pegawai penyiasat jika ia mendapati bahawa penahanan lanjutan tidak perlu atau suspek masih boleh memberi kerjasama walaupun tidak ditahan reman (masih berada dalam jagaan polis) dengan

\footnotetext{
54 Sinar Harian, 2015.

55 Zulfakar Ramlee, "Penyiasatan di dalam Kanun Acara Jenayah Syariah di Malaysia", dalam Abdul Monir Yaacob \& Siti Shamsiah Md.Supi (pnyt), Pendakwaan dan Penyiasatan Konsep dan Amalan. (Kuala Lumpur: IKIM, 2003), 120.
} 
syarat ia yakin bahawa suspek tidak akan melarikan diri daripada pihak penguatkuasa. ${ }^{56}$

Penahanan reman dengan penahanan selepas dibicarakan adalah merupakan dua perkara yang sangat berbeza. Hal ini kerana penahanan reman adalah bagi tujuan siasatan atau "investigative detention" manakala penahanan selepas perbicaraan adalah merupakan suatu bentuk hukuman setelah disabitkan bersalah oleh pihak mahkamah. Di samping itu, penahanan reman adalah sangat penting bagi mengelakkan suspek menimbulkan sebarang risiko seperti menganggu para saksi mahupun bahan bukti. Apabila perkara yang dikhuatiri ini berlaku, ia berkemungkinan akan menjejaskan proses siasatan seterusnya membawa kepada ketidakadilan perjalanan perbicaraan kes itu sendiri. ${ }^{57}$

Di samping itu juga, Lord Denning berpendapat, tidak dinafikan setiap individu dalam masyarakat itu mempunyai hak asasi masing-masing. Namun, bagi mengelakkan kekacauan berlaku dalam sesebuah masyarakat, maka pihak berkuasa diberi kuasa untuk menangkap dan menahan seseorang yang disyaki melanggar undang-undang yang telah ditetapkan. Perkara ini membuktikan bahawa penahanan reman dibolehkan dan merupakan suatu keperluan bagi mengekalkan keamanan sejagat. KC Vohrah J turut bersependapat dengan Lord Denning yang mengatakan bahawa penahanan reman adalah merupakan suatu keperluan yang tidak dapat disangkal kerana ianya dibuat bagi tujuan kebaikan dan mendatangkan manfaat yang menjurus kepada keadilan. ${ }^{58}$

Selain itu, Jagmohan Mishra turut berpendapat bahawa sekiranya pihak tertuduh tidak berada dalam tahanan reman, maka berkemungkinan besar mereka enggan datang ke mahkamah meskipun atas arahan pihak mahkamah sendiri sekaligus akan menyebabkan proses perbicaraan terpaksa ditangguhkan. ${ }^{59}$ Begitu juga dengan contoh yang lain seperti proses soal siasat akan dapat dilaksanakan dengan lancar dan proses perbicaraan turut

56 Lee Chong Fook et. al, The Process of Criminal Justice, 120.

57 Sinar Harian. 2015.

58 Jerald Gomez, "Police Powers and Remand Proceedings", The Malayan Law Journal Articles. Vol 2 (2003): cxxix-clix.

59 Jagmohan Mishra, Human Rights Perspective on Detention and Prisoners (India: Akansha Publishing, 2011), 96. 
dapat dijalankan dengan baik tanpa ada sebarang gangguan disebabkan kelakuan yang tidak wajar seperti contohnya tertuduh memusnahkan bahan bukti dan sebagainya. ${ }^{60}$ Hal ini turut dipersetujui oleh Wafaa' Yusof. Menurut beliau, penahanan pra perbicaraan (penahanan reman) dianggap sebagai salah satu tatacara penyiasatan bagi meletakkan pesalah berada di bawah jagaan pihak berkuasa, memudahkan proses soal siasat mampu menghalang pesalah daripada melarikan diri dan sebagainya. ${ }^{61}$

Tambahan lagi, dalam satu laporan di Australia yang bertajuk "Factors that Influnce Remand in Custody", penahanan reman secara umumnya merupakan suatu bentuk "pemenjaraan" ke atas diri seseorang namun hakikatnya ianya bukan merupakan suatu hukuman atau sekatan kebebasan ke atas diri seseorang. Ianya bertujuan untuk mengambil kenyataan daripada tertuduh untuk dijadikan sebagai satu keterangan yang boleh digunapakai dalam mahkamah. Penahanan reman ini juga merupakan salah satu strategi pengurangan kadar jenayah dalam masyarakat atau dalam Bahasa Inggerisnya berbunyi "a crime reduction strategy under the rubric of 'intelligence-led policing". Matlamat sebenar kewujudan penahanan reman adalah untuk memastikan integriti dan kredibiliti sistem keadilan di mahkamah. Matlamat yang kedua adalah untuk melindungi masyarakat sejagat seperti mengelakkan daripada suspek mengancam para saksi, mangsa dan lain-lain lagi serta dalam masa yang sama, dapat memelihara hak-hak pihak defendan. Pihak berkuasa masih memelihara hak-hak orang yang ditahan kerana prinsip asas dalam sistem keadilan negara adalah seseorang itu adalah tidak bersalah sehingga dirinya dibuktikan bersalah. Mereka tidak boleh ditahan sewenang-wenangnya kecuali dengan keizinan daripada pihak mahkamah. Selain itu juga, mereka berhak menerima perubatan jika didapati mereka sakit dan mereka tidak boleh disakiti oleh pihak berkuasa sama sekali. ${ }^{62}$

60 Sue King et.al, "The Remand Strategy: Assessing Outcomes", Current Issues in Criminal Justice, Vol 19 (3) (2008): 327-344.

${ }^{61}$ Wafaa' Yusof, "Tatacara Penahanan Pra Perbicaraan Jenayah Syariah di Malaysia: Analisis Menurut Pandangan Fuqaha", Journal of Contemporary Islamic Law. Vol 1 (1) (2016): 39-54.

62 Sue King et.al, Factors that Influnces Remand in Custody (Australia: University of South Australia, 2005), 56. 
Terakhir, pada pendapat pengkaji, penahanan reman yang paling baik dan sempurna adalah penahanan yang paling singkat tempohnya namun dalam masa yang sama, segala proses penyiasatan dapat dilaksanakan dengan lancar sehinggakan semua maklumat yang ingin disiasat menjadi lengkap. Tambahan lagi, bagi memastikan reman itu berlangsung dalam tempoh yang singkat, pihak pegawai penyiasat yang terlibat mestilah memastikan perjalanan "defence services" (sama ada peguam persendirian mahupun bantuan guaman) dilaksanakan dengan cepat dan sempurna bagi memudahkan proses perbicaraan yang akan datang. Kedudukan penahanan reman dalam KPJ tidak dapat dinafikan lagi sebagai salah satu mekanisme pra perbicaraan. Hal ini kerana penahanan seperti ini adalah untuk menyoal siasat tertuduh, mengelakkan tertuduh daripada tidak menghadirkan diri semasa perbicaraan di mahkamah dan sebagainya.

\section{KESIMPULAN}

Secara ringkasnya, antara sebab kemungkinan peruntukan berkaitan penahanan reman tidak diperuntukkan dalam Enakmen Tatacara Jenayah Syariah negeri-negeri di Malaysia berdasarkan pandangan beberapa PPA dan PPS adalah kerana pernyataan suspek yang diperoleh semasa soal siasat suspek tidak diterima pakai sebagai keterangan dalam mahkamah. Jadi pada pendapat mereka, mengapa perlunya penahanan reman sedangkan pernyataan suspek semasa penahanan tersebut langsung tidak boleh diterima pakai? Sedangkan objektif utama keperluan penahanan reman ini adalah untuk menjalankan soal siasat ke atas tertuduh sekaligus menerima pernyataan tertuduh itu sebagai keterangan dalam mahkamah. ${ }^{63}$ Kedua, terdapat juga beberapa orang PPA yang memberi alasan yang kurang munasabah pada pendapat penulis iaitu penahanan reman tidak dapat dilaksanakan ekoran ketiadaan tempat atau bilik yang khusus. ${ }^{64}$ Pada pandangan penulis, alasan ini kurang wajar dan munasabah kerana golongan ini sepatutnya mencari

\footnotetext{
63 Wafaa' binti Yusof, “Tatacara Pra Perbicaraan Jenayah Syariah Terhadap Suspek Kanak-kanak: Analisis Perundangan di Malaysia”, Tesis Dr. Fal, (Fakulti Undang-undang: Universiti Kebangsaan Malaysia, 2017), 140.

64 Utusan Malaysia. 2011.
} 
jalan ikhtiar untuk mewujudkan bilik atau tempat khas bagi tujuan meletakkan suspek-suspek pada peringkat pra perbicaraan. Selain itu, terdapat juga segelintir PPA yang mengatakan bahawa mereka sebenarnya menjalankan siasatan ke atas suspek dan sekiranya tidak dapat disempurnakan dalam tempoh 24 jam, mereka menahan reman suspek bagi tujuan siasatan sekaligus menerima pernyataan suspek sebagai keterangan dalam mahkamah. Perkara ini jelasnya telah menyebabkan wujudnya lakuna dalam undangundang Syariah kerana PPA membuat interpretasi enakmen sendiri mengikut pandangan masing-masing. Lakuna seperti inilah yang menyebabkan segelintir pihak pegawai penguatkuasa agama bercanggah pendapat sesama sendiri seterusnya menyebabkan timbulnya kecelaruan dari segi amalan pihak penguatkuasa agama. ${ }^{65}$

Manakala menurut persepktif hukum syarak, penahanan sementara ini adalah antara tindakan atau perilaku kawalan oleh pihak berkuasa ke atas tertuduh dengan syarat mestilah diizinkan oleh qadi. Pelaksanaannya termasuk di bawah kategori al-siyāsah shar 'iyyah yang telah diperakui oleh syarak. Pihak hakim boleh menggunakan budi bicaranya dalam menentukan samada seseorang itu perlu atau tidak ditahan reman dan semuanya bergantung ke atas keadaan dan jenis kes yang terlibat. Penyalahgunaan kuasa oleh pihak berkuasa dapat dielakkan dengan adanya penahanan seperti ini. Sekiranya tatacara ini diterima pakai dan dikuatkuasakan, maka keselamatan para saksi, masyarakat awam bahkan keselamatan pihak suspek atau tertuduh sendiri terpelihara dan terjamin. Jika tidak, pelbagai masalah timbul sekali gus secara tidak langsung akan memberi kesan negatif terhadap proses pendakwaan dan perbicaraan di mahkamah.

Oleh itu, penulis berpandangan bahawa penahanan reman ini perlu diguna pakai dan diterima ke atas semua kesalahan yang memerlukan kepada penyiasatan lanjutan dan penyiasatan yang tidak dapat diselesaikan dalam tempoh 24 jam. Di samping itu juga, setelah penulis meneliti kajian literatur dan penulisan ilmiah,

65 Ahmad Azam Shariff, "Prosedur Siasatan dan Pendakwaan Jenayah Syariah: Lakuna dalam Peruntukan Undang-undang Jenayah Syariah di Malaysia", Tesis Dr. Fal, (Fakulti Undang-Undang: Universiti Kebangsaan Malaysia, 2012), 281. 
penulis percaya bahawa penahanan reman atau sementara ini tidak menyalahi hukum syarak dan prinsip siyasah syariyyah serta ia wajar diperuntukkan dalam Enakmen Tatacara Jenayah Syariah (ETJS) negeri-negeri di Malaysia.

\section{RUJUKAN}

Al-Quran.

Ahmad Azam Shariff. "Prosedur Siasatan dan Pendakwaan Jenayah Syariah: Lakuna dalam Peruntukan Undangundang Jenayah Syariah di Malaysia". Tesis Dr. Fal, Fakulti Undang-undang: Universiti Kebangsaan Malaysia, 2012.

Akta Prosedur Jenayah (KPJ).

Amin al-Jarumi. Perspektif Umum Prosiding Mahkamah dalam Syariat Islam: Prinsip-prinsip Prosoding Mahkamah dalam Syariat Islam. Shah Alam: UPENA, 2006.

Anon. 2015. Fatwa Arab Saudi 2015.

Anon. 2008. Iran's Human Rights Watch 2008, Vol 20 (1).

Ashraf Md. Hashim. Rights of Suspect and Accused Under Islamic and Malaysian Law. Kuala Lumpur: International Law Book Services, 2004.

'Awdah, 'Abdul Qādi. Al-Tashrī' al-Janā '̄̄ al-Islām Muqāranan bi al-Qānūn al-Waḍi 'ì. Bayrūt: Dār al-Kitāb al-'Arabī, 2003.

Al-Bukhārī. Șaḥiḥ al-Bukharī. Beirūt: Dār Ibn Kathīr, 1993.

Daud Muhammad. “Konsep Penyiasatan di dalam Islam”. Dalam Abdul Monir Yaacob \& Siti Shamsiah Md.Supi (pnyt). Pendakwaan dan Penyiasatan Konsep dan Amalan. Kuala Lumpur: IKIM, 2003.

Enakmen Tatacara Jenayah Syariah (ETJS).

Al-Khațtābī, Abū Sulaymān Hamd b. Muhammad. Ma 'lim alSunā̄ Sharh Sunā̄ Abū Dāwud. Beirut: Mu'assassat alRisalah, 2012. 
Ibn Qayyīm, Abū 'Abd Allāh Muḥammad Ibn Abī Bakr. I'lām al-Muwāqqī'an Rabb al- 'Ālamīn. Bayrūt: Dār al-Kutub al'Ilmiyyah, 1993.

Ibn Qayyīm, Abū 'Abd Allāh Muḥammad Ibn Abī Bakr. al-Ṭuruq al-Hukmiyyah fì al-Siyāsah Shar 'iyyah. Bayrūt: Dār alKutub al-'Ilmiyyah, 1995.

Ibn Taymiyyah, Ahmad 'Abd-Halim. Majmū' Fatāwa. Kuwait: Matba'ah al-Hukumah, 1966.

Jagmohan Mishra. Human Rights Perspective on Detention and Prisoners. India: Akansha Publishing, 2011.

Jerald Gomez. "Police Powers and Remand Proceedings". The Malayan Law Journal Articles. Vol 2 (2003).

Lee Chong Fook et. al. The Process of Criminal Justice: Investigation and Pre-Trial Proceedings. Singapura: LexidNexis, 2010.

Al-Mawardī, 'Alī bin Muhammad. Al-Ahkam al-Sulțāniyyah. AlQāhirah: Dār al-Ḥadīth, 1988.

Md. Akhir Yaacob. Sistem Pemerintahan dalam Islam. Kuala Lumpur: Bahagian Hal Ehwal Islam Jabatan Perdana Menteri, 1986.

Mimi Kamariah. Pentadbiran Keadilan Jenayah di Malaysia. Kuala Lumpur: Universiti Malaya, 1991.

Muhammad Fathi Yusof. Keindahan Undang-undang Islam. Selangor: Best Brains Asia Publications, 2017.

Muhammad Shirazi. The Rights of Prisoners According to Islamic Teachings. London: Fountain Books, 2002.

Muhammad Tahmid. Menggapai Hukum Pidana Ideal Kemaslahatan Pidana Islam dan Pembaruan Hukum Pidana Nasional. Jogjakarta: Deepublish, 2016.

Al-Mursafāwī, Muhammad 'Abdullah Muhammad. Al-Habs AlIhtityātī. Iskandariyyah: Dār al-Fikr al-Jami'i, 2006. 
Muslim, Abū al-Ḥusayn 'Asākir ad-Dīn Muslim Ibn al-Ḥajjāj. Sharh al-Arba'ìn al-Nawāwiyyah. Beirut: Mu'assasah alRisalah, 1422H.

Al-Nubayhi, Abū Ḥassan. Tamlīh Qudhat al-Andalus. Beirut: Dār al-'Alaq al-Jadīd, 1980.

Al-Qāri, 'Alī bin Sulțān Muḥammad. Mirqat al-Mafātiḥ Sharh Mishkatun al-Mașābiḥ. Beirut: Dar al-Fikr, 2002.

Al-Qurtubī, Muhammad bin Aḥmad bin Ab̄̄ Bakr bin Farạ̣ Abū Abdullah. Al-Jāmi' li Ahkam al-Quran al-Mubīn Lamma Tadmanahu min al-Sanah wa'ayyu al-Furqan. Kaherah: Dar al-Sha'bi, 1372H.

Sa'eedy 'Ali. "Different Cases of Imprisonment in Islam". Journal of Faculty of Law and Political Science (FALL). vol 41 (3) (2011): 185-199.

'Umar Sa'īd Ramaḍān. Mabādī' Qānūn al-Ijrā'āt al-Janā'iyyat. Al-Qāhirah: Dār al-Nahụah al-Arabiyyah, 1993.

Salman Muhammad. "The Right to a Fair Trial under Saudi Law of Criminal Procedure". Tesis Kedoktoran: Brunel University (London), 2013.

Al-Ṣana'ānī, Abī Bakr 'Abd al-Razzāq Ibn Hammān Ibn Nāfi'. Mușannaf. Beirut: Maktabah al-Islāmī,T.th.

Al-Sarakhsī, Muhammad bin Aḥmad. al-Mabsūṭ. Beirut: Dar alMa'rifah, 1993.

Shamrahayu Abd Aziz. Issues on Enforcement of Islamic Criminal Law in Malaysia. Selangor: Malik Teraju Ria, 2011.

Shamrahayu Abd Aziz. Isu Penguatkuasaan Undang-undang Jenayah Syariah di Malaysia. Kuala Lumpur: Dewan Bahasa dan Pustaka, 2016.

Al-Sijistānī, Abū Dāwud Sulaymān Ibn al-Ash'ath al-Azdi. Sunā̄ AbūDāwud. Misr: Mu’assasah Qurțubah, 1995M.

Siti Zalikhah Md. Nor. "Kanun Jenayah Syariah Suatu Penilaian". dalam Abdul Basir Mohammad et. al. (pnyt). Isu Syariah 
dan Undang-undang Siri 4. Bangi: Jabatan Syariah UKM, 2012.

Siti Zubaidah Ismail. Undang-undang Tatacara Jenayah Syariah. Kuala Lumpur: Dewan Bahasa dan Pustaka, 2016.

Srimurugan Alagan. The Criminal Procedure Code: A Commentary. Selangor: Sweet \& Maxwell, 2015.

Sue King et.al. Factors That Influnces Remand in Custody. Australia: University of South Australia, 2005.

Sue King et.al. "The Remand Strategy: Assessing Outcomes". Current Issues in Criminal Justice. Vol 19 (3) (2008).

Surūr, Aḥmad Fatḥ̄i. al-Wasìt fì Qānūn al-Ijrā'àt alJazā 'iyyatī alQāhirah: Dār al-Nahụah al-'Arabiyyah, 1985.

Al-Tirmīdhī, Abū 'Isa Muhammad bin 'Isa. Sunan al-Tirmìdhī. Mesir: Mațba'ah Mușțafā al-Bābī al-Ḥalabī, 1962.

Wafaa' Yusof. "Tatacara Penahanan Pra Perbicaraan Jenayah Syariah di Malaysia: Analisis Menurut Pandangan Fuqaha". Journal of Contemporary Islamic Law. Vol 1 (1) (2016): 39-54.

Wafaa' binti Yusof. "Tatacara Pra Perbicaraan Jenayah Syariah Terhadap Suspek Kanak-kanak: Analisis Perundangan di Malaysia”. Tesis Dr. Fal, Fakulti Undang-undang: Universiti Kebangsaan Malaysia, 2017.

Wan Roslili Abd Majid \& Najibah Mohd Zain. "Isu dalam Penahanan dan Pemulihan Banduan di Malaysia". Jurnal Kanun. Vol 27 (1) (2015): 144-168

Zainal Azam Abd Rahim. "Acara Jenayah dan Keperluan Pembuktian: Satu Tinjauan Ringkas Mengenai Beberapa Isu Berkaitan dari Perspektif Syariah dan Fikah". Dalam Abdul Monir Yaacob \& Siti Shamsiah Md. Supi (pnyt). Pendakwaan dan Penyiasatan: Konsep dan Amalan. Kuala Lumpur: Institut Kefahaman Islam Malaysia, 2003. 
Jurnal Fiqh, No. 15 (2018) 87-116 